\title{
TAXONOMIC STUDIES ON THE FAMILY TORTRICIDAE (TORTRICOIDEA: LEPIDOPTERA) FROM NORTHWESTERN INDIA -- TRIBE EUCOSMINI (OLETHREUTINAE)
}

\author{
H.S. Rose and H.S. Pooni \\ Department of Zoology, Punjabi University, Patiala, Punjab 147002, India \\ E-mail: profhsrose@yahoo.com
}

\begin{abstract}
Sixteen species belonging to eleven genera viz., Rhopobota Lederer, Acroclita Lederer, Strepsicrates Meyrick, Gibberifera Obraztsov, Loboschiza Diakonoff, Crocidosema Zeller, Epinotia Hübner, Helictophanes Meyrick, Acanthoclita Diakonoff, Ancylis Hübner and Eucosma Hübner belonging to the tribe Eusosmini (Olethreutinae) of the family Tortricidae have been collected from northwestern India and dealt with taxonomically. Key to the presently examined genera has been prepared on the basis of characters such as the labial palpi, antennae, costal fold, anal fold, wing venation and male and female genitalic characteristics. Further, keys to the species of the genera Epinotia Hübner and Eucosma Hübner represented by more than one species have also been furnished. Eucosma pseudostrigulata is being reported as new to science. Species such as Rhopobota grypodes Meyrick, Epinotia corynetes Diakonoff, Acanthoclita iridorphna Meyrick and Eucosma prominens Meyrick are being reported for the first time from India, whereas, Acroclita corinthia Meyrick, Gibberifera glaciata Meyrick, Epinotia canthonias Meyrick, Helictophanes dryocoma Meyrick, Ancylis lutescens Meyrick, Eucosma stereoma Meyrick and E. melanoneura Meyrick have been collected for the first time from the area, under reference. Besides giving an illustrated account of the new species, the genitalic account of the already known species have been added to improve their diagnosis.
\end{abstract}

\section{KEYWORDS}

Acanthoclita, Acroclita, Ancylis, Crocidosema, Epinotia, Eucosma, Eucosma pseudostrigulata sp. nov., Eucosmini, genitalia, Gibberifera, Helictophanes, Lepidoptera, Loboschiza, Rhopobota, Strepsicrates

AbBreviations

FRI: Forest Research Institute; NHM: Natural History Museum; PUP: Punjabi University, Patiala; SOC: Socius; T.A.: Tuba analis; UHF: University of Horticulture and Forestry; UN: Uncus.

While characterizing the tribe Eucosmini of the subfamily Olethreutinae (Tortricidae), Horak and Brown (1991) have stated that it contains about 1,000 species in over 125 genera. Following this characterization, the material collected from northwestern India has been found to belong to 11 genera, viz., Rhopobota Lederer, Acroclita Lederer, Strepsicrates Meyrick, Gibberifera Obraztsov, Loboschiza Diakonoff, Crocidosema Zeller, Epinotia Hübner, Helictophanes Meyrick, Acanthoclita Diakonoff, Ancylis Hübner and Eucosma Hübner (Razowski, 1977). Accordingly, the present communication deals with 16 species including one new to science. Besides giving an illustrated account of the new species, a key to the presently studied Indian genera, in addition to the keys to the species of the genera Epinotia Hübner and Eucosma Hübner represented by more than one species have also been formulated.

\section{Methodology}

In view of nocturnal behaviour of the Eucosmin moths, their collection was done with the help of portable light traps fitted with $125 \mathrm{w}$ mercury vapour lamp. The traps were installed near the ground amongst bushes as moths are generally weak fliers. In addition to this, a mercury vapour lamp was also hung along a white cloth sheet secured to a wall or directly over a plain white wall. Specimens were then collected singly in the small glass killing tubes. Each collected specimen was spread in the small spreading box after pinning it through the middle of mesothorax. The spread specimens were preserved in the insect storage boxes, fumigated with naphthalene balls. Before the specimens were preserved in the boxes, each was furnished with data such as date of collection, name of the locality, collection altitude and name of the collector etc. To prepare the permanent slides of the wings, the method discussed by Common (1970) and advocated by Zimmerman (1978) has been followed. To study the external male and female genitalia, the method suggested by Robinson (1976) has been followed with slight modification.

\section{Observations}

Besides giving original reference of each taxon, complete synonymy has been listed to update the information of different Indian species. The names of the larval host plants have also been included to make the information more useful to future workers.

\section{Tribe Eucosmini}

Eucosmini Meyrick, 1909, J. Bombay Nat. Hist. Soc., 19: 582.

Type-genus: Eucosma Hübner [1823], Zuträge Samml. exot. Schmett., 2: 28.

Diagnosis: Forewing often with costal fold in male; hindwing with $\mathrm{CuA}_{1}$ and $\mathrm{M}_{3}$ stalked; male genitalia with valva with large basal excavation, cucullus well developed, delimited by a neck, often hairy; female genitalia with a sclerotized ring near entrance of ductus seminalis.

\section{Rhopobota Lederer}

Rhopobota Lederer, 1859, Wien, Ent. Monatschr. 3: 124.

Type-species: Tortrix naevana Hübner, [1817], Samml. eur. Schmett. 7: pl. 41, fig. 261. 


\section{Rhopobota grypodes Meyrick}

Acroclita grypodes Meyrick, 1912, J. Bombay Nat. Hist. Soc., 21: 856. Clarke, 1958, Cat. type-spec. Microlepid. BMNH described by Edward Meyrick, 3: 272, pl. 135 figs. 4-4a; pl. 136 figs. I-Ib.

Acroclita vulturina Meyrick, 1936, Exot. Microlepid., 4: 610; Diakonoff, 1950, Bull. Brit, Mus. (Nat. Hist.) Ent., I(4): 278. Rhopobota grypodes; Diakonoff, 1982, Zool. Verh. Leiden, 193: 54.

Material examined: 7 males, 23.iv.1999, 1 male, 19.iv.2000, FRI, Dehradun, Uttaranchal, 700m; 1 male, 13.iv.1999, Renuka Lake, Sirmour, Himachal Pradesh, 740m.

Distribution: Sri Lanka, Java (Clarke, 1958).

\section{Diagnostic features}

Male genitalia (Fig. 1): Uncus absent; socii triangular; tegumen broad, high, shoulders produced, gives out two long, narrow and strong arms from its lower part beyond middle, arms joined apically, each strongly clavate, densely hairy, rounded at apex; vinculum reduced $\mathrm{V}$-shaped; juxta plate-like; valva moderate; narrow basally, costa arched terminally, sacculus narrow, long, basally expanded with a row of moderate spines along ventral margin, a single strong seta exactly in the middle of valva, cucullus very broad, abruptly dilated, top rounded, marginally finely hairy; aedeagus short, gradually narrowing apically, lower lip pointed; caulis band-like, moderate in size.

Female genitalia: Not examined.

Alar expanse: Male 11-12mm.

\section{Larval host plant: Unknown}

Remarks: On the basis of a single male specimen from Maskeliya (Sri Lanka), Meyrick (1912) named a new species gryopodes under the genus Acroclita Hübner. Clarke (1958) published a photograph of its genitalia (slide no. JFGC-6933). The presently examined phenon comprising nine individuals have been found to be conspecific on the basis of the male genitalia and has been identified as Arcoclita gryopodes Meyrick. The diagnostic characters of the species lie in the fact that the apex of the forewing is prominently falcate and underside of the hindwing has a narrow elongate patch of blackish scales extending from one-fourth to beyond middle. The alar expanse of the presently examined male specimens varies form $13-15 \mathrm{~mm}$, whereas, the one published earlier is $17 \mathrm{~mm}$ (Meyrick, 1912). Meyrick (1936) reported another species, i.e., Acroclita vulturina from Java for which he has examined only two female specimens having an alar expanse between 15 to $17 \mathrm{~mm}$. However, the latter species has been synonymized under A. gryopodes by Diakonoff (1950), who later on proposed a new combination of the latter as Rhopobota gryopodes (Meyrick). Accordingly, the latter arrangement is followed here. The species is recorded for the first time from India.

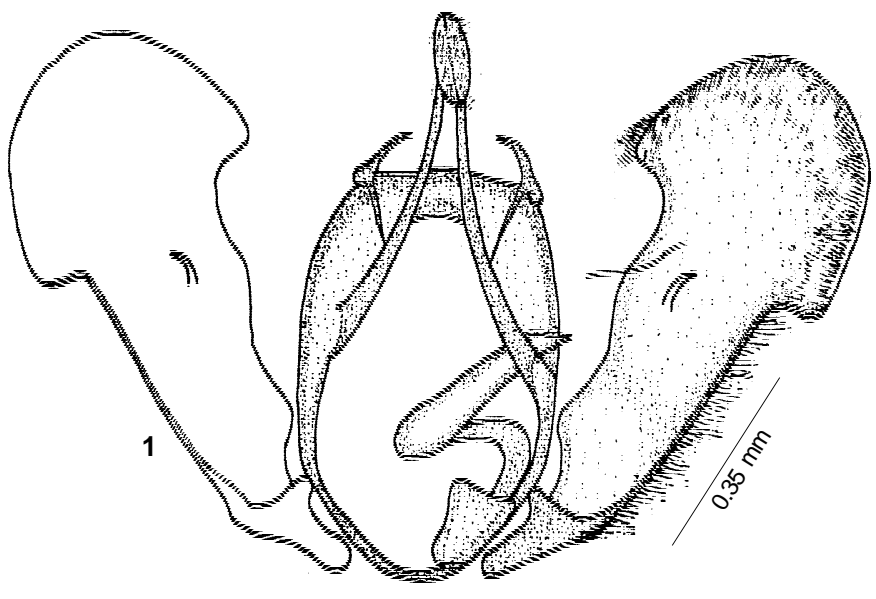

Figure 1. Rhopobota grypodes Meyrick. 1 - Male genitalia - ventral view

\section{Acroclita Lederer}

Acroclita Lederer, 1859, Wien, Ent. Monatschr., 3: 123, 329. Acrolita [sic] Fernald, 1908, Genera Tortricidae Types: 59. Acrocita [sic] Turner, 1946, Trans. R. Soc. N.S.W., 70: 197. Type-species: Paedisca arctana Staudinger, 1859, Ent. Ztg. Stettin, 20: 232, by subsequent monotypy.

\section{Acroclita corinthia Meyrick}

Acroclita corinthia Meyrick, 1912, J. Bombay Nat. Hist. Soc., 21: 858; Diakonoff, 1950, Bull. Br. Mus. (Nat. Hist.) Ent., I (4): 277.

Material examined: 1 male, 21.iv.1999, FRI, Dehradun, Uttaranchal, $700 \mathrm{~m}$.

Distribution: India (Khasi Hills), Sri Lanka (Meyrick, 1912).

\section{Diagnostic features}

Male genitalia (Figs. 2-5): Uncus bipartite, tips pointing laterally; socii represented by long fine hair; valva leaf-like, basally broad, tip pointed, cucullus broad basally, bilobed, upper lobe long, gradually narrowing distally, ending in the form of a strong seta, lower lobe small, somewhat triangular, ending in the form of a moderate seta; aedeagus long, vesica without cornuti.

\section{Female genitalia: Not examined.}

\section{Alar expanse: Male $12 \mathrm{~mm}$.}

\section{Larval host plant: Unknown}

Remarks: While reporting Acroclita corinthia as a new species from British India (Ceylon, India; Khasi Hills), Meyrick (1912) has mentioned that its hindwings are characteristic due to blackish veins besides a black patch on the costal margin on the underside. Ap art from this, the male genitalia completely agrees with that of the lectotype (Maskeliya, Ceylon, Pole, .5.06, slide no. JFGC-6950) given by Clarke (1958). The species seems to be quite rare in northwestern India from where it is being redescribed 


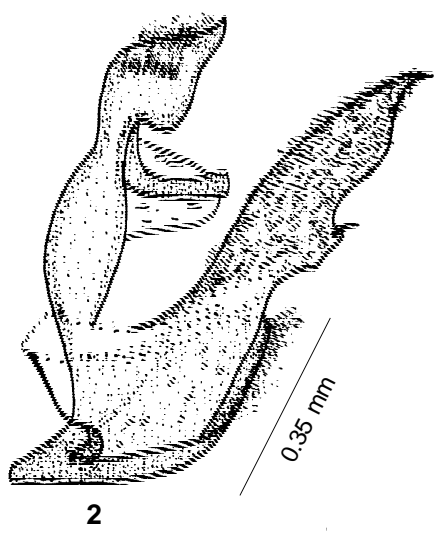

2

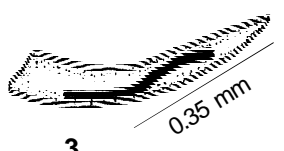

3

Figure 2-5. Acrolita corinthia Meyrick.

2 - Male genitalia-lateral view; 3 - Aedeagus;

4 - Uncus-Ventral view; 5 - Right valva

on the basis of a single specimen.

\section{Strepsicrates Meyrick}

Strepsicrates Meyrick, 1888, Trans. N.Z. Inst., 20: 73.

Strepsiceros Meyrick, 1881, Proc. linn. Soc. N.S.W., 6: 678. Typespecies: Sciaphila ejectana Walker, 1863, List Specimens lepid. Insects Colln Br. Mus., 28: 350, by subsequent designation by Fernald, 1908, Genera Tortricidae Types: 44, 61. (nom. praeocc,) Phthinolophus Dyar, 1903, Proc. Ent. Soc. Wash., 5: 307. Typespecies: Phthinolophus indentanus Dyar, 1903, ibidem, 5: 307, by monotypy.

Phthenolophus [sic] Busck, 1910, Proc. Ent. Soc. Wash., 12: 312. Type-species: Sciaphila ejectana Walker, 1863, List Specimens lepid. Insects Colln Br. Mus., 28: 350, by subsequent designation (for Strepsiceros Meyrick, 1881) by Fernald, 1908, Genera Tortricidae Types: 44, 61. Replacement name for Strepsiceros Meyrick.

\section{Strepsicrates rhothia Meyrick}

Spilonota rhothia Meyrick, 1910, Trans. Ent. Soc. Lond., 1910: 368. Diakonoff, 1950, Bull. Br. Mus. (Nat. Hist), Ent., I: 285. Fletcher, 1921, Mem. Dep. Agric. India (Ent.), 6: 43. - 1932, Imp. Council Agric. Res., Sci Monogr., 2: 18, pl. II.

Strepsicrates rhothia; Clarke, 1958, Cat. type-spec. Microlepid. BMNH described by Edward Meyrick, 3: 596, pl. 297, figs. 2-2a.

Material examined: 2 female, 1 male, 24.vii.2000, PUP, Patiala, Punjab, 250m; 1 male, 24.viii.2000, FRI, Dehradun, Uttaranchal, $700 \mathrm{~m}$.

Distribution: India (Bengal), Sri Lanka, Mauritius (Clarke, 1958).

\section{Diagnostic features}

Male genitalia (Figs. 6-8): Uncus represented by two thin dorso-

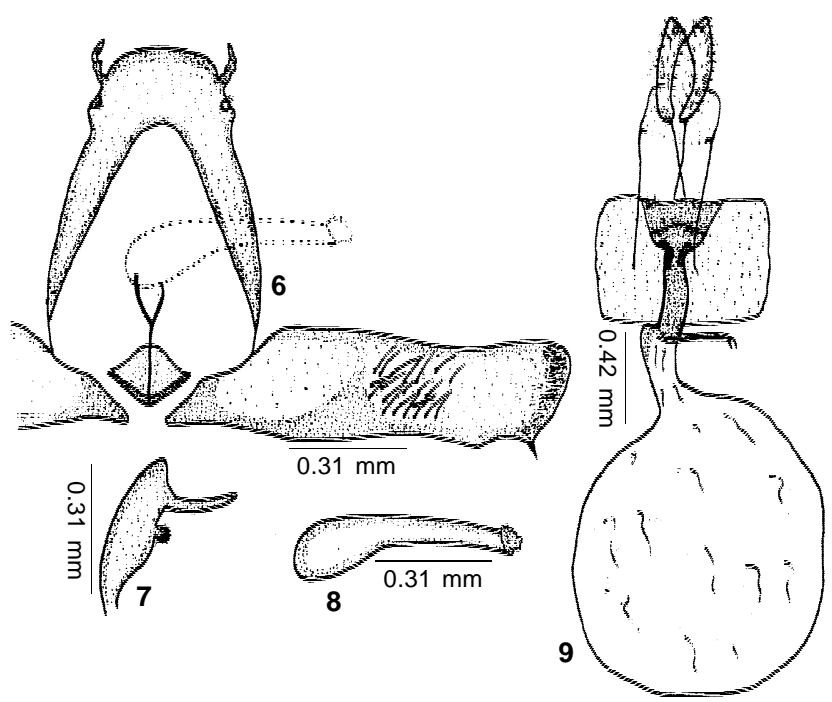

Figure 6-9. Strepsicrates rhothia Meyrick. 6 - Male genitalia - ventral view; 7 - Tegumen - lateral view; 8 - Aedeagus; 9 - Female genitalia - ventral view

lateral free arms; socii represented by very small lobes, the latter immediately below arms of uncus, sparsely hairy; tegumen broad, high, top rounded; vinculum thin, U-shaped; juxta triangular, plate-like; valva simple, moderately broad and long, basal excavation large, sacculus narrow; cucullus somewhat differentiable, neck broad, top rounded dorsally, distal margin with a row of fine hair, ventral margin produced into a small triangular prominence, a beak-like prominence occurring ventrodistally, ending in a stout seta, inner surface of valva with a group of fine setae medially; aedeagus moderate, globular anteriorly, slightly curved, gradually narrowing posteriorly, lower lip pointed, vesica without cornuti; caulis moderate in size.

Female genitalia (Fig. 9): Papillae anales flat, long, somewhat slender, anterior apophyses slightly longer than posterior; sterigma cup-shaped, with very fine hair anteriorly and posteriorly; seventh sternite moderately sclerotized, finely granulated; ostium bursae broad; ductus bursae small, proximal half sclerotized; an oval protuberance in the middle of ductus bursae; corpus bursae large, globular, signum absent, ductus seminalis enter at the end of sclerotized region.

Alar expanse: Male and female 12-14mm.

Larval host plant: Eugenia jambolana (India) (Fletcher, 1921), Psidium guava (Sri Lanka) (Clarke, 1958).

Remarks: The species rhothia Meyrick has been reported under the genus Spilonota Hübner by Meyrick (1910) and Diakonoff (1950). The latter author has also designated its lectotype, as the former did not do so at the time of naming it as a new species. However, Clarke (1958) after the examination of the male genitalia of the lectotype has suggested a new combination of this species under Strepsicrates Meyrick. Upon comparison with the male genitalia, the lone specimen presently dealtwith is reported as 
Strepsicrates rhothia (Meyrick). It may also be added that besides India (Pusa Bengal, three specimens), the species has also been reported from Ceylon (Maskeliya, 4 specimens) and Mauritius (1 specimen) (Clarke, 1958). This is a new record of this species from northwestern India.

\section{Gibberifera Obraztsov}

Gibberifera Obraztsov, 1946, Z. wien. ent. Ges., 30: 26, 35.

Type-species: Penthina simplana Fischer von Röslerstamm, [1836] 1834, Abbildungen Ber. Ergänz. Schmett. Microlepid.: 38 , by original designation.

\section{Gibberifera glacialta Meyrick}

Cydia glaciata Meyrick, 1907, J. Bombay Nat. Hist. Soc., 17: 143.

Eucosma glaciata: Clarke, 1958, Cat. type-spec. Microlepid. BMNH described by Edward Meyrick, 3: 364, pl. 181, fig. 4.

Gibberifera simplana glaciata: Diakonoff, 1964, Veröff. Zool. StSamml. Munch. 8: 49, pl. 24, fig. 4, pl. 26, figs 13,14.

Gibberifera simplana: Kawabe and Sakurai, 1988, Yugato (113): 110, fig. 29. Kawabe, 1989, Microlepid. Thai. (2): 54, fig. 82. Kawabe and Komai, 1992, in Heppner, Lepid. Taiwan, 1(2): 107. [Misid.].

Material examined: 1 female, 1 male, 23.iv.1999, FRI, Dehradun, Uttaranchal, 700m.

Distribution: India (Khasi Hills), Pakistan, Nepal, Thailand, Taiwan, China (Kawabe \& Nasu, 1994).

\section{Diagnostic features}

Male genitalia (Figs. 10-12): Uncus slender, stick shaped, sinuate, curved downward and beyond middle upwards, forked apically, arms of fork disto-laterally directed, finely setosed dorsally except exreme apex; tuba analis well developed triangular in outline;
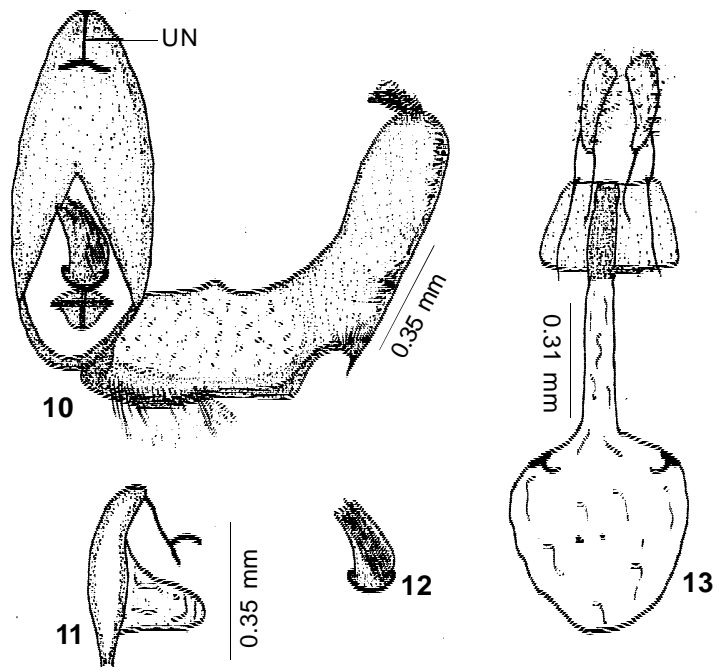

Figures 10-13. Gibberifera glaciata Meyrick. 10 - Male genitalia - ventral view; 11 - Tegumen - lateral view; 12 - Aedeagus; 13 - Female genitalia - ventral view tegumen broad and high, shoulders rounded; vinculum reduced; valva long and broad, constricted and curved in middle, basal excavation large, finely bristled; sacculus setosed basally, terminally producing a small protuberance, cucullus long, broad, more or less rectangular in outline, neck short, basally bearing a moderate spine ventrally, inner surface finely hairy, top broad and rounded, with a brush of long hair; aedeagus short, broad, with a bunch of deciduous cornuti and a small non-deciduous cornuti at tip.

Female genitalia (Fig. 13): Papillae anales flat, narrow; anterior apophyses as long as posterior; sterigma plate-like, rectangular; seventh sternite moderately sclerotized; ostium bursae moderate; ductus bursae broad, moderately long, posterior one-third sclerotized, remaining membranous, slightly expanding distally; corpus bursae globular, bearing two thorn-shaped signae proximo-laterally.

Alar expanse: Male and female 11-12mm.

Larval host plant: Willow (Salix sp.) (Saliaceae) (Kawabe \& Nasu, 1994).

\section{Lobaschiza Diakonoff}

Loboschiza Diakonoff, 1968 (Jan.), Bull. U.S. Nat. Mus., 257: 93. Rhadinoscolops Obraztsov, 1968 (Sept.), J. N.Y. Ent. Soc., 76: 187. Type-species: Pyralis koenigiana Fabricius, 1775, Syst. Ent.: 653 , by original designation.

Type-species: Argyroploce clytocarpa Meyrick, 1920, Exot. Microlepid. 2: 349, by original designation.

\section{Loboschiza koenigiana Fabricius}

Pyralis koenigiana Fabricius, 1775, Syst. Ent.: 653. -1781, Sp. Insect., 2: 286.

Pyralis koenigana; Fabricius, 1787, Mantissa Insect., 2: 237. 1794, Syst. Ent., 3 (2): 279.

Hemerosia aurantiana Pryer, 1877, Descriptions of new species of Lepidoptera from North China, Cist. Ent., 2: 235, pl. 4, fig. 12. Coptoloma aurantiana; Swinhoe and Cotes, 1889, Cat. Moths of India: 699.

Laspeyresia aurantiana; Meyrick, 1911, Proc. Linn. Soc. N.S.W., 36: 292. - 1929, in de Joannis, Annals Soc. Ent. Fr., 98: 8721. 1935, in Caradja and Meyrick, Lepid. Chinesischen Provinzsien: 64.

Laspeyresia koenigana; Fletcher, 1914, S. Indian Ins.: 450, fig, 328. - 1920, Mem. Dep. Agric. India (Ent.), 6: 62. Obraztsov, 1959, Tijdschr. Ent., 102: 193. Okano, 1959, Iconogr. Ins. Jap. Col. Nat. Edita, I: 259, pl. 174, fig. 16.

Laspeyresia aurana Matsumura, 1931 (nec fabricius, 1775), 6000 Ill. Ins. Jap.: 1071, no. 2150.

Eucosma koenigiana; Diakonoff, 1941, Treubia, 18: 405. Anarmonia koenigiana; Fletcher, 1932, Imp. Council Agric. Res., Sci Monogr., 2: 33, pl. 21. Diakonoff, 1948, Bull. Mus. Nat. Hist., 20: 348. - 1953, Verh. Kon. Ned. Akad. Wet., Nat., Ser. 2, 49 (3): 161.

Enarmonia koenigana; Diakonoff, 1949, Bijdr. Dierk., 28: 348. Inoue, 1954, Check List Lepid. Japan: 91. Issiki, 1957, Icon. Het. 
Jap. Col. Nat., I: 57, pl. 8, figs. 254.

Rhodinoscolops koenigianus; Obraztsov, 1968, J N.Y. Ent. Soc., 76: 160, figs. 14-17.

Material examined: 1 female, 2 males, 24-25.iv.1999, 1 male, 23.ix.1999, FRI, Dehradun, Uttaranchal, 700m; 4 females, 14 males, 4-30.iv.1998, 12 females, 16 males, 2-18.iii.1998, 1 female, 1 male, 14.ii.1999, 1 male, 16.ii.1999, 1 male, 30.iii.1999, PUP, Patiala, Punjab, $250 \mathrm{~m}$.

Distribution: India, Ceylon, Burma, China, Japan, Malay Archipelago, new Guinea, Australia (Diakonoff, 1982).

\section{Diagnostic features}

Male genitalia (Figs. 14-15): Uncus absent; socii flap-like, hairy; tuba analis hardly traceable; tegumen weak and slender, slightly broadening towards vinculum; vinculum U-shaped, juxta small, shield shaped; valva long and curved, costa with costal hook, basal excavation extending upto middle, sacculus bearing fine dense hair along ventral margin, cucullus finely setosed, dilating distally, bilobed, upper lobe broad, rounded, oblique, lower lobe reduced into a long beak-like structure, directed oblique, opposite to upper lobe; aedeagus moderately long, slightly curved, tapering posteriorly, cornuti absent; caulis long.

Female genitalia (Fig. 16): Papillae anales flat, broad; anterior apophyses as long as posterior apophyses; ostium bursae broad; antrum well developed, tube-like; ductus bursae broad; corpus bursae globular in shape; signum absent; a ring of sclerotization near entrance of ductus seminalis.

\section{Alar expanse: Male and female 12-13mm.}

Larval host plant: Melia azedarachata (Fletcher, 1921).

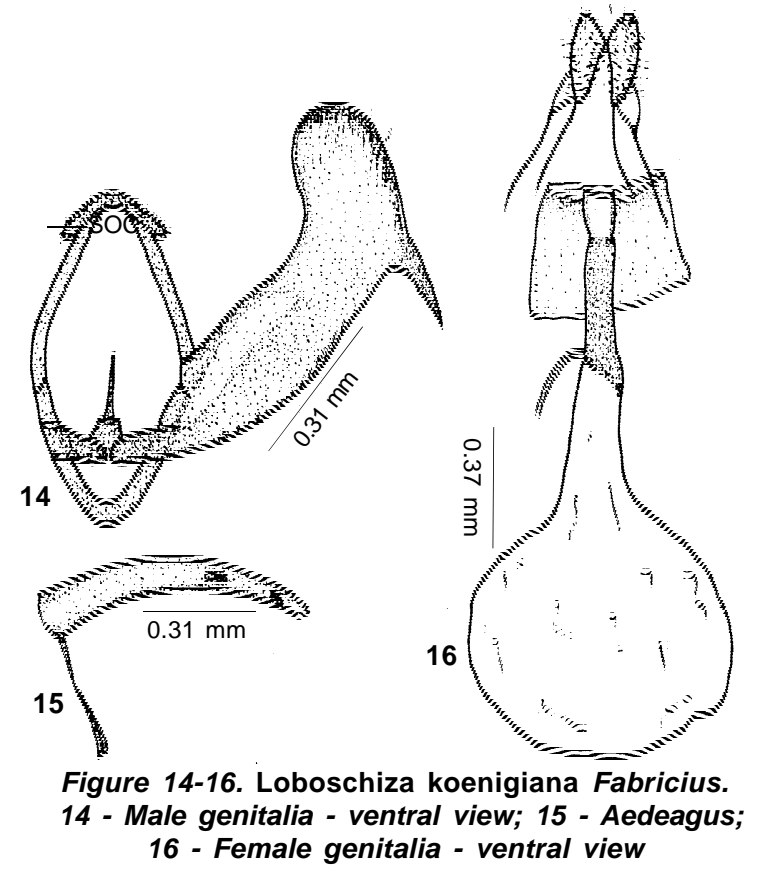

February 2005 Zoos' Print Journal 20(2): 1751-1765
Remarks: According to Robinson et al. (1994), various species of the genus Loboschiza Diakonoff form a natural group in having similar bright pattern of orange, red or crimson colouring or brightly yellow edged with dark purple colouration are distributed in India, Sri Lanka, Nepal, Burma, Thailand, Philippines and extend up to Australia. In South East Asia, the genus is represented by four species and the present sample has been identified as Loboschiza koenigina Fabricius (Diakonoff, 1982). The placement of the genus under the tribe Eucosmini has been followed from Diakonoff (1982), who synonymized the genus Rhodinoscolops proposed by Obraztsov (1968) with the species, under reference, as its type-species. Regarding distribution of the species, Fletcher (1921) has mentioned that it is available in plains of India. In the absence of any precise distribution record, no mention is made as to whether it is being recorded for the first time or is an additional record from the Siwaliks in northwestern India. However, the species is very common and the entire sample has been collected from the plains/foothills of Punjab.

\section{Crocidosema Zeller}

Crocidosema Zeller, 1847, Isis Oken, Leipzig 1847: 721.

Crocidosoma (sic) Walker, 1863, List Specimens lepid. Insects Colln Br. Mus., 27: 279.

Type-species: Crocidosema plebejana Zeller, 1847, ibidem, 1847: 721 , by monotypy.

\section{Crocidosema plebejana Zeller}

Crocidosema plebejana Zeller, 1847, Isis: 721. Heinemann, 1849, Schmett. Eur: 241. Staudinger and Wocke, 1871, Cat. Lepid. Europ. Faun.: 263, no. 1269. Eppelsheim, 1881, Sttet. Ent. Zeitschr.: 379. Meyrick, 1881, Proc. Linn, Soc. N.S.W., 6: 659. 1886, Trans. Ent. Soc. Lond., 1886: 276: - 1928, Rev. Handbook Brit. Lepidoptera.: 539. Walsingham, 1891, Proc. Zool, Soc. London: 506; - 1897, ibidem.: 127, no. 174. - 1907, in Sharp, Fauna Hawaiiensis, I (5): 675, pl. fig. 15. Staudinger and Rebel, 1901, Cat. Lepid. Pal. Faun., 2: 110, no. 1968. Kennel, 1910, Pal. Tortr.: 468, pl. 18, figs. 66, 67. - 1910, in Spuler, Schmett. Eur., 2: 273, pl. 85, fig. 45. Philpott, 1923, Trans. N.Z. Inst., 59: 475, fig. 10. Heinrich, 1923, Bull. U.S. Natn. Mus., 123: 190, figs. 10, 29, 29a, 325. Lhomme, 1935, Cat. Lép. Fr. et Belg., 2: 330. Clarke, 1958, Cat. type-spec. Microlepid. BMNH described by Edward Meyrick, 3: 319, pl. 158, figs. I-Ia, 2-2a, 3-3a. Hannemann, 1961, Tierw. Deutschl., 48: 154, no. 315 (also spelled plebiana by some authors).

Penthina altheana Mann, 1855, Verh. Zool.-bot. Ges Wien: 555. Paedisca lavaterana Milliére, 1862, Icon. Et descry. Chénilles et Lép. Inédits: 290, 310, pl. 34, figs. 9-13.

Grapholitha peregrinana Möschler, 1866, Berl. Ent. Zeitschr.: 139.

Stenoptycha obscura Wollanston, 1879, Ann. Mag. Nat. Hist., (5) $3: 341$.

Proteopteryx blackburni Butler, 1881, Ann. Mag. Nat. Hist., (5) 7: 393-394. Willcocks, 1916, Insect Pests Egypt, I: 390, pl. 7, fig. 5. Eucosma plebeiana Meyrick, 1911, Trans. Linn. Soc. (2) 14: 268; 1914, Ent. Mitt., Suppl., 3: 48.

Crocidosema ptiladelpha Meyrick, 1917, Trans. Ent. Soc. Lond., 
1917: 18. Clarke, 1955, Cat. Type-spec. Microlepid. BMNH described by Edward Meyrick, 1: 264; 1958, ibidem, 3: 319, pl. 158, figs. I-Ia.

Crocidosema synneurota Meyrick, 1926, Trans. Ent. Soc. Lond., 74: 276. Clarke, 1955, Cat. Type-spec. Microlepid. BMNH described by Edward Meyrick, 1: 301. - 1958, Cat. Type-spec. Microlepid. BMNH described by Edward Meyrick, 3: 319, pl. 158 , figs, $2-2 \mathrm{a}$

Material examined: 1 female, 2 males, 24-25.iv.1999, 1 male, 23.ix.1999, FRI, Dehradun, Uttaranchal, 700m; 1 female, 16.vi.1999, Dharampur, Solan, Himachal Pradesh, 1500m; 1 male, 2.iii.1998, 1 male, 14.ii.1999, 1 female, 1 male, 16.ii.1999, 1 male, 30.iii.1999, PUP, Patiala, Punjab, 250m.

Distribution: Cosmopolitan (Robinson et al., 1994).

\section{Diagnostic features}

Male genitalia (Figs. 17-18): Uncus small, pointed, hairy; socii well developed, long, broad, somewhat oval, pad-like, with backwardly directed dense hair, broadest in middle, somewhat curved, tip rounded; tuba analis well developed, strongly sclerotized; tegumen thin, long; vinculum weak; juxta triangular, plate-like; valva peculiar, long, medially strongly constricted, twisted ventrally, basal excavation moderate, triangular; sacculus broad, triangular, with a group of fine bristles medially, cucullus broad, delimited by a very narrow neck, twisted ventrally, broadest sub-basally, gradually narrowing, apex somewhat pointed, ventrally directed, inner surface with fine dense hair, lower margin with small stout setae, apex with three long spines; aedeagus moderate, slightly curved lower lip pointed, vesica with a sheaf of long cornuti; caulis thin, band-like.

Female genitalia (Fig. 19): Papillae anales long, slender, anterior apophyses as long as posterior; sterigma hairy, seventh sternite moderately sclerotized; ostium bursae moderate; ductus bursae, short, broad, somewhat expanding distally; corpus bursae moderate in size, globular in shape, with two horn like signae,
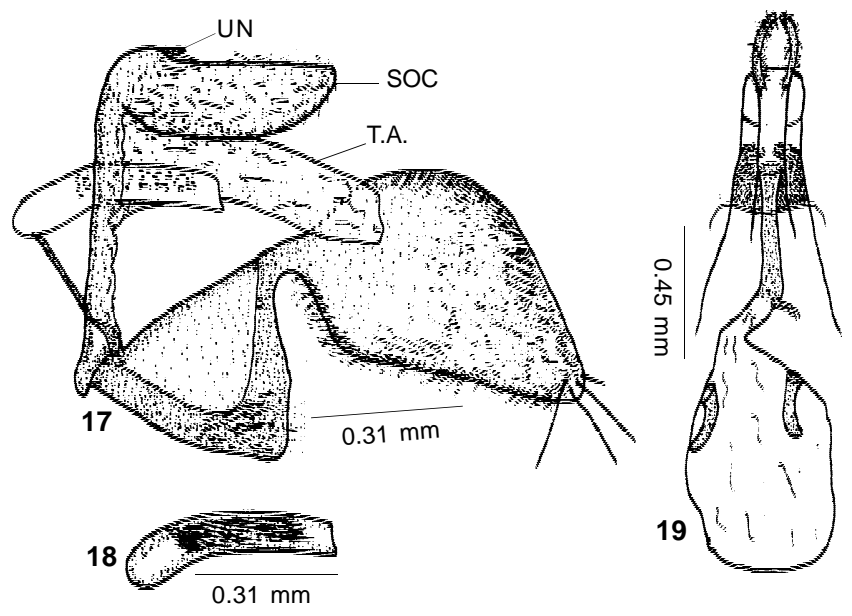

Figures 17-19. Crocidosema plebejana Zeller. 17 - Male genitalia - ventral view; 18 - Tegumen - lateral view; 19 - Female genitalia - ventral view latter broad, slightly curved; ductus seminalis enter in the middle of distal half of ductus bursae.

Alar expanse: Male and female $15-17 \mathrm{~mm}$.

Larval host plants: Malva sylvestris, M. parviflora, Malvastrum spicatum, Malvaciscus drummondi, Althaea rosea, Lavatera arborea, Hibiscus esculentus, Militaris, Rosa sinensis, Abutilon indicum (Diakonoff, 1982).

Remarks: While enlisting Crocidosema plebejana Zeller, Diakonoff (1982) has clarified that the correct spelling of this species are plebejana not plebiana (Clarke, 1958). The species Crocidosema plebjana appears to be cosmopolitan in distribution and has been reported from an elevation range of 200m (Lima, Peru) to 1500m (Ecuador, Huigra) (Clarke, 1958). The latter author has examined a large sample ( 58 specimens) of this species in the NHM, London and has recorded that the alar expanse of this species varies between $11-15 \mathrm{~mm}$. The male genitalia of this species is unique as far as the shape of its valva is concerned. The latter is strongly constricted medially and the cucullus is relatively quite broad. The cucullus is delimited by a very narrow neck and twisted ventrally with its lower margin carrying small and stout setae, which are generally shed during dissection.

\section{Epinotia Hübner}

Epinotia Hübner, [1825] 1816, Verz. Bekannter Schmett.: 377. Astatia Hübner [1825] 1816, Verz. Bekkannter Schmett: 377. Type-species: Tortrix parmatana Hübner, [1817], Samml. Eur. Schmett. 7: pl. 40, fig. 253, 254, by subsequent designation by Fernald, 1908, Genera Tortricidae Types: 7, 54 (but cited as Phalaena solandriana Linnaeus).

Acalla Hübner, [1825] 1816, Verz. Bekkannter Schmett.: 385. Type-species: Tortrix ophtalmicana Hübner, [1799], Samml. Eur. Schmett. 7: pl. 9, fig. 51, by subsequent designation by Fernald, 1908, Genera Tortricidae Types: 12, 55, but misspelt as ophthalmicana).

Poecilochroma Stephens, 1829, Nom. Br. Insects: 47. Typespecies: Phalaena solandriana Linnaeus, 1758, Syst. Nat. (Edn 10), 1: 532, by subsequent designation by Westwood, 1840, Introd. Mod. Classif. Insects, 2: 108.

Paedisca Treitschke, 1830, in Ochsenheimer, Schmett. Eur., 8:188. Type-species: Tortrix parmatana Hübner, [1817], Samml. Eur. Schmett., 7: pl. 40, figs. 253, 254, by subsequent designation by Duponchel, 1834, in Godart and Duponchel, Hist. Nat. Lépid. Papillons Fr. 9: 22.

Paragrapha Sodoffsky, 1837, Bull. Soc. Imp. Nat. Moscou, 1837 (6): 92, 97. Type-species: Tortrix parmatana Hübner, [1817], Samml. Eur. Schmett. 7: pl. 40, figs. 253, 254, proposed as replacement name for Paedisca Treitschke, 1830.

Halonota Stephens, 1852, List Specimens Br. Anim. Colln Br. Mus., 10: 45. Type-species: Pyralis populana Fabricius, 1787, Mantissa Insect. 2: 382, by subsequent designation, by Walsingham and Durrant, 1901, Entomologist's Mon. Mag. 37: 190.

Catastega Clemens, 1861, Proc. Ent. Soc. Philad., 1: 86. Type- 
species: Catastega timidella Clemens, 1861, ibidem, 1: 87, by subsequent designation by Busck, 1903, Proc. U.S. Natn. Mus., 25: 852 .

Proteopteryx Walsingham, 1879, Illust. Typical Specimens Lepid. Heterocera Colln. Br. Mus., 4: 68. Type-species: Proteopteryx emarginana Walsingham, 1879, ibidem, 4: 68, pl. 76, figs. 2-6, by original designation and monotypy.

Type-species: Phalaena similana Hübner, 1793, Samml. Aurserlesenger Vögel und Schmett.: 13, pl, 71, by subsequent designation by Fernald, 1908, Genera Tortricidae Types: 8, 54.

Discussion: Diakonoff (1982) listed the species lantana Busck and canthonias Meyrick under the genus Epinotia Hübner besides giving an illustrated account of Epinotia corynetes as a new species from Sri Lanka. During the course of present studies, latter two species have been collected from the Siwaliks in North West India. On the basis of examination of their male genitalia, these have been found to be broadly congeneric in respect of characters such as i) reduced uncus, ii) fleshy, densely hairy, pad-like socii and iii) basally broad valva with broad sacculus bearing a bristly prominence medially and cucullus narrower than sacculus. However, this natural grouping could not be confirmed on the basis of the female genitalia due to paucity of collection.

\section{Epinotia corynetes Diakonoff}

Epinotia corynetes Diakonoff, 1982, Zool. Verh. Leiden 193: 59.

Material examined: 1 male, 23.iv.1999, 1 male, 25.iv.1999, FRI, Dehradun, Uttaranchal, 700m.

Distribution: Sri Lanka (Diakonoff, 1982).

\section{Diagnostic features}

Male genitalia (Figs. 20-22): Uncus moderate in size, apex rounded, bristly; socii well developed, oval, slightly curved, somewhat triangular, broadest in middle, densely hairy, top round-pointed;

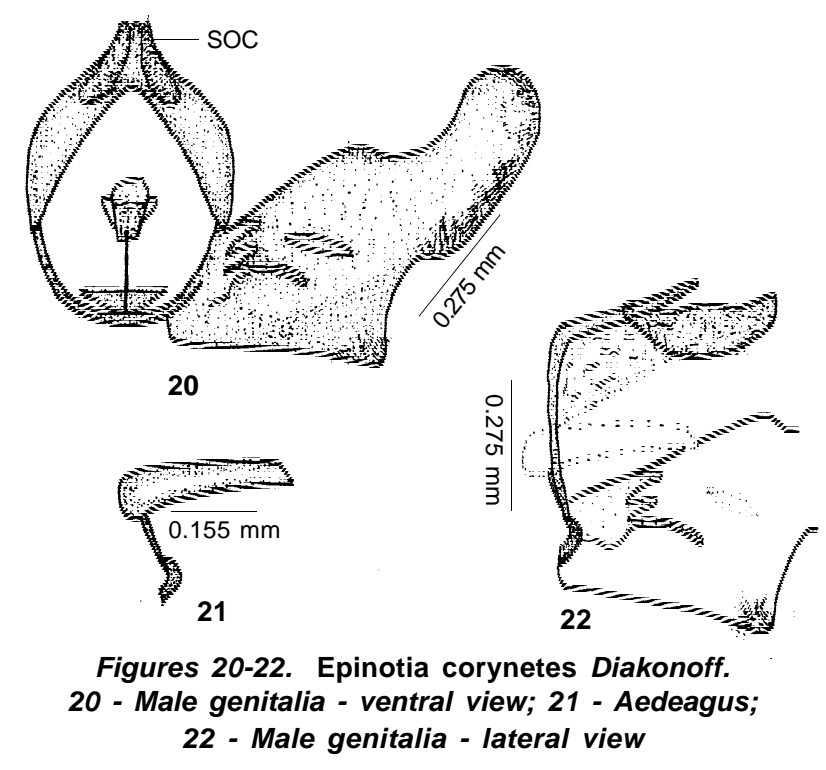

tegumen broad, shoulders rounded; vinculum V-shaped; juxta small, triangular, plate-like; valva broad at base, costa straight, ending in a small prominence, the latter finely hairy, sacculus broad, with a large prominence almost opposite prominence of costa, finely bristly, cucullus moderately broad, somewhat sinuate, neck broad, bearing fine hair at lower margin, apex rounded, somewhat straight, curved, finely hairy; aedeagus moderately broad, long, slightly narrowed posteriorly, lower lip pointed, vesica without cornuti; caulis slender.

Female genitalia: Not examined.

Alar expanse: Male $11 \mathrm{~mm}$.

\section{Larval host plant: Unknown}

Remarks: Diakonoff (1982) examined three male specimens (2 without abdomens) collected from Sri Lanka (Dist. Ratanpura) and proposed a new species i.e., Epinotia corynetes. In the present studies, two males collected from Dehradun (FRI) have been found to completely conform to the description of the aforesaid species and have, accordingly, been named as $E$. corynetes Diakonoff. Both the males have been dissected and their genitalia examined with great precision. It has been observed that the deciduous cornuti either may remain intact as in one specimen or are shed as in the other specimen. This gives an impression as if both these specimens are not truly conspecific, which otherwise are on the basis of morphological characters including other genitalic details. It may be added that the occurrence of this type of phenomenon need to be precisely noted before reporting such variable individuals as a different species. The phenomenon of absence of the deciduous cornuti is very common and it has been noted that sometimes the cornuti are present in the corpus bursae of the females (pers. obser.). It is thus reiterated that though the aedeagus is generally quite species specific yet the taxa in which cornuti are deciduous in nature need to be decided cautiously.

\section{Epinotia canthonias Meyrick}

Acroclita canthonias Meyrick, 1920, Exot. Microlepid. 2: 343. Fletcher, 1932, Imp. Council Agric. Res., Sci Monogr., 2:19. Clarke, 1958, Cat. Type-spec. Microlepid. BMNH described by Edward Meyrick, 3: 268, pl. 133 figs, 2-2a.

Epinotia canthonias; Diakonoff, 1982, Zool. Verh. Leiden, 193: 59 , fig. 36.

Material examined: 1 male, 10.ix.1998, UHF, Nauni, Solan, Himachal Pradesh, 1360m.

Distribution: India (Bengal, Pusa).

\section{Diagnostic features}

Male genitalia (Fig. 23): Uncus small, apex bipartite, dorsally directed; socii small, drooping pads, moderately hairy; tegumen narrow, high, shoulders rounded; vinculum weak, V-shaped; juxta plate-like, triangular; valva simple, moderate in size, slightly constricted beyond middle, sacculus long, convex, medially beset with fine hair, terminally with a group of 8-10 moderate 


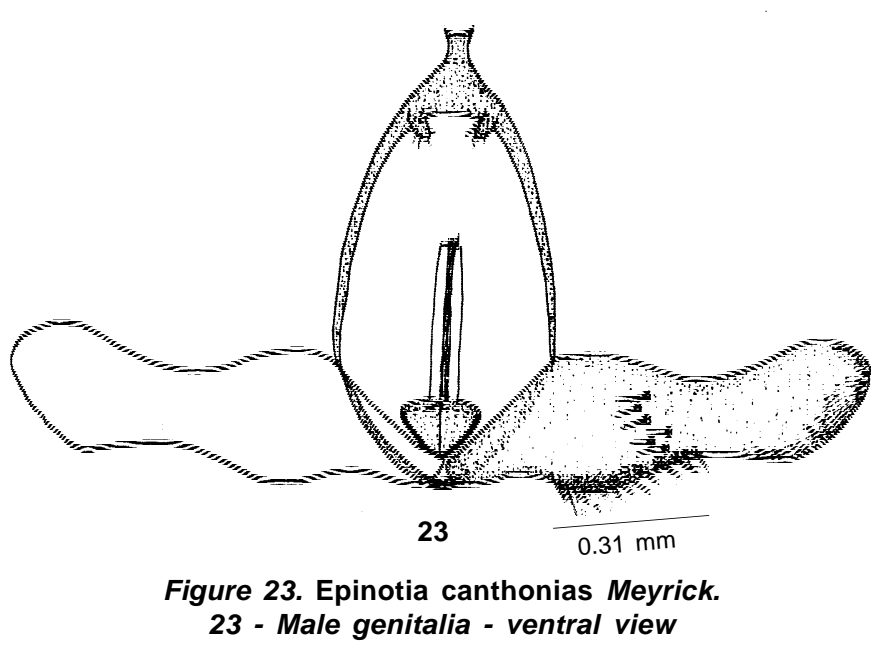

setae, cucullus moderate, neck small, broad, slightly curved, ventral margin with a row of fine hair, top somewhat rounded; aedeagus almost straight, vesica with a sheaf of long cornuti.

Female genitalia: Not examined.

Alar expanse: Male $8.5 \mathrm{~mm}$.

Larval host plant: Ficus glomerata (Clarke, 1958).

Remarks: While recording new collection data in Sri Lanka, Diakonoff (1982) has proposed Epinotia canthonias (Meyrick) as a new combination, which is being followed in the present studies, as well. The species has earlier been recorded under the genus Acroclita (Meyrick, 1920; Clarke, 1958). Though the species represents a new record from the area, under reference, yet seems to be quite rare.

\section{Helictophanes Meyrick}

Helictophanes Meyrick, 1881, Proc. Linn. Soc. N.S.W., 6: 637. Type-species: Helictophanes uberana Meyrick, 1881, ibidem, 6: 639, by subsequent designation by Fernald, 1908, Genera Tortricidae Types: 43, 61.

\section{Helictophanes dryocoma Meyrick}

Argyroploce dryocoma Meyrick, 1916, Exot. Microlepid., 2: 21. Helictophanes dryocoma; Clarke, 1958, Cat. Type-spec. Microlepid. BMNH described by Edward Meyrick, 3: 407, pl. 202 fig. 3-3a.

Material examined: 1 male, 3.vi.1998, 1 male, 22.iv.1999, 1 male, 23.iv.1999, FRI, Dehradun, Uttaranchal, 700m; 1 male, 31.viii.1998, PUP, Patiala, Punjab, 250m.

Distribution: India (Southern India, Sheveroy Hills), Sri Lanka (Diakonoff, 1982).

\section{Diagnostic features}

Male genitalia (Figs. 24-25): Uncus absent; socii moderate,

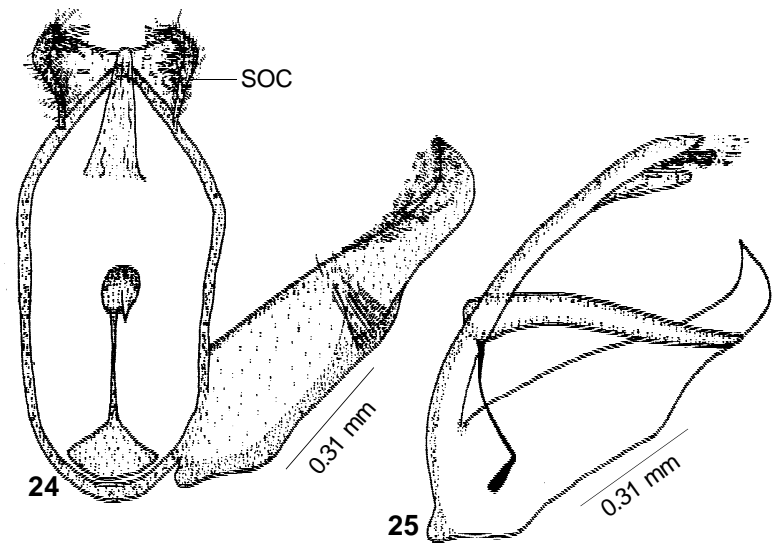

Figures 24-25. Helictophanes dryocoma Meyrick. 24 - Male genitalia - ventral view; 25 - Male genitalia lateral view

triangular pads, dorsally directed, with dense long hair; tegumen slender, high, somewhat rectangular; tuba analis moderately sclerotized; vinculum weak; valva broader at base, abruptly narrowing at middle, sacculus with 5-7 fine long hair terminally, cucullus narrower, top produced into a triangular beak-like prominence, dorsally beset with long fine hair, top rounded ventrally; aedeagus long, slender, slightly curved, gradually narrowing posteriorly, upper lip pointed; caulis long, thin, bandlike.

Female genitalia: Not examined.

Alar expanse: Male 9-10mm.

\section{Larval host plant: Unknown}

Remarks: Helictophanes dryocoma Meyrick has earlier been reported from Sheveroy Hills in southern India (Meyrick, 1916) and Sri Lanka (Diakonoff, 1982) with record of one specimen each from the respective country. The present specimen is the third male of this species so far known. The female of this species is obviously still unknown. The species appears to be quite rare.

\section{Acanthoclita Diakonoff}

Acanthoclita Diakonoff, 1982, Zool. Verh. Leiden, 193: 27.

Type-species: Eucosma balanoptycha Meyrick, 1910, Rec. Indian Mus., 10: 255, by original designation.

\section{Acanthoclita iridorphna Meyrick}

Acroclita iridorphana Meyrick, 1936, Exot. Microlepid., 4: 609. Diakonoff, 1950, Bull. Br. Mus. (Nat. Hist.), Ent., I: 278. Clarke, 1958, Cat. type-spec. Microlepid. BMNH described by Edward Meyrick, 3: 275, pl. 136, figs. 4-4a.

Material examined: 3 males, 21-23.iv.1999, FRI, Dehradun, Uttaranchal, 700m; 1 male, 29.viii.1999, PUP, Patiala, Punjab, 250m.

Distribution: Sri Lanka, Taiwan (Clarke, 1958). 


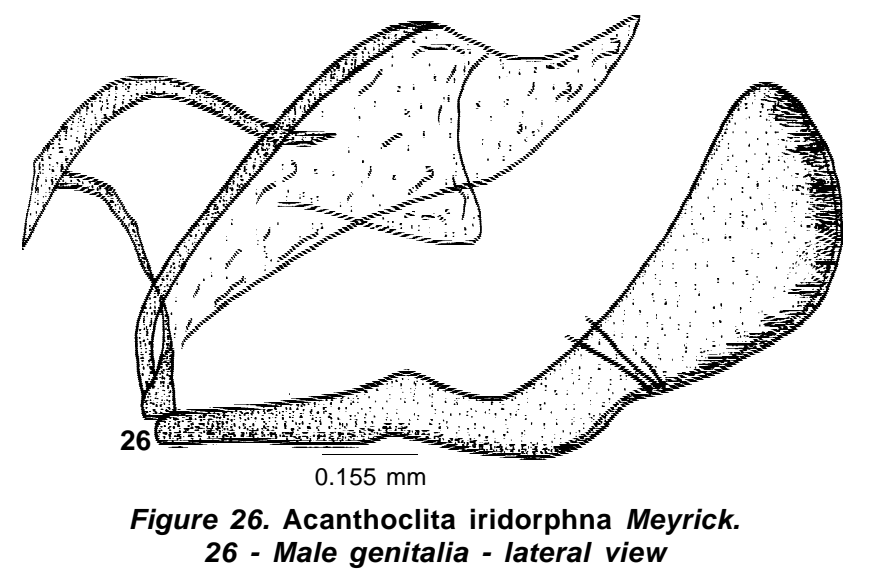

Diagnostic features

Male genitalia (Fig. 26): Uncus and socii absent; tuba analis moderately sclerotized; tegumen broad, apex produced, conical; vinculum reduced; valva long, slender, obliquely dilated distally, somewhat clavate, costa produced into a small prominence terminally, sacculus narrow; cucullus gradually dilated, convex ventrally, with a characteristic fringe of long slender spines along lower margin, two basal spines very long; aedeagus long, slender, strongly curved at right angle almost in the middle, posteriorly pointed, vesica without cornuti, caulis long, strongly built.

Female genitalia: Not examined.

Alar expanse: Male 12-13mm.

\section{Larval host plant: Unknown}

Remarks: Diakonoff (1950) while examining the type-specimens of certain Eucosmidae and Carposinidae has enlisted Acroclita iridorphna Meyrick as an independent species besides designation of a male specimen as its holotype and a female as its allotype. In fact, Meyrick (1936) did not designate any types at the time of naming of this species. In this regard, Clarke (1958) has pointed out this error with a remark, "since no type was selected by Meyrick and each specimen is of equal value". Contrary to Diakonoff (1950), Clarke (1958) designated the male (dated 17.xi.32) as lectotype rather than the holotype, which is a correct approach as per ICZN. Diakonoff (1982) has created an anomaly by doubtfully mentioning Acroclita iridorphna Meyrick as a synonym of Eucosma balanoptycha Meyrick (typespecies of Acanthoclita Diakonoff) on one hand and by listing iridorphna Meyrick as a new combination under the genus Acanthoclita Diakonoff on the other hand. On the basis of present studies, particularly the male genitalia and the wing venation, it is being felt that though the species iridorphna conforms to the diagnosis of the type-species Acanthoclita balanoptycha yet differs from it in minutes of structure of the valva and aedeagus in the male genitalia. The present study, in fact, suitably justifies the new combination proposed by Diakonoff (1950), who somehow or the other did not assign any reason for this proposal. The species Acanthoclita iridorphna has originally been known from Formosa (now Taiwan) (Meyrick,
1932). As such, the genus is represented by four species i.e., $A$. balanoptycha (Meyrick), A. iridorphna (Meyrick), A. acrocroa Diakonoff and A. balia Diakonoff, the latter two from Sri Lanka. The species is being reported for the first time from India.

\section{Ancylis Hübner}

Ancylis Hübner, [1825], Verz. Bekannter Schmett.: 376.

Epicharis Hübner, [1825] 1816, Verz. Bekannter Schmett.: 376. Type-species: Tortrix derasana Hübner, [1813], Samml. Eur. Schmett. 7: pl. 32, fig. 206.

Anchyolopera Stephens, 1829, Nom. Br. Insects: 177. Typespecies: Pyralis lundana Fabricius, 1777, Genera Insect.: 294. Anticela Stephens, 1834, Illust. Br. Ent. (Haustellata) 4: 113. Type-species: Tortrix harpana Hübner, [1799], Samml Eur. Schmett. 7: pl. 13, fig. 77.

Philalcea Stephens, 1835, Illust. Br. Ent. (Haustellata) 4: 396. Type-species: Tortrix harpana Hübner, [1799], Samml. Eur. Schmett. 7: pl. 13, fig. 77.

Phoxopteris Treitschke, 1829, in Ochsenheimer, Schmett. Eur., 7: 232. Type-species: Tortrix siculana Hübner, [1799], Samml. Eur. Schmett. 7: pl. 13, fig. 79.

Phoxopteryx Sodoffsky, 1837, Bull. Soc. Imp. Nat. Moscou, 1837 (6): 93 (unjustified emend.)

Sidera Guenée, 1845, Annls Soc. Ent. Fr. (2) 3: 156. Type-species: Tortrix achatan [Denis and Schiffermüller], 1775, Ankükndung Syst. Werkes Schmett. Wienergegend: 131.

Sidera [sic!] Stainton, 1859, Manual Br. Butterflies Moths, 2: 196.

Phoxopteria [sic!] Walcott, 1923, J. Dep. Agric. P. Rico, 7: 201.

Type-species: Tortrix harpana Hübner, [1799], Samml Eur. Schmett. 7: pl. 13, fig. 77, by subsequent designation by Fletcher, 1929, Mem. Dep. Agric. India (Ent.) 11: 14.

\section{Ancylis lutescens Meyrick}

Ancylis lutescens Meyrick, 1912, Exot. Microlepid., 1: 32. Diakonoff, Bull. Br. Mus. (Nat. Hist.) Ent.,1 (4): 281.

Material examined: 1 female, 6 males, vii.1998, 4 females, 10 males, ix.1998, 1 female, 1 male, x.1998, 1 female, xi.1998, 1 male, xii.1998, 1 male, ii.1999, 1 male, iii.1999, 1 male, iv.1999, 1 female, 1 male, viii.1999, 4 males, ix.1999, 2 males, x.1999, 2 males, iii.2000, 1 male, v.2000, PUP, Patiala, Punjab, 250m.

Distribution: India (Bengal, Assam) (Fletcher, 1921).

\section{Diagnostic features}

Male genitalia (Figs. 27-28): Uncus absent; socii well developed, broad, large, triangular, sparsely setosed; tegumen thin, round; vinculum weak; valva broad, triangular in outline, narrow basally; sacculus small, separable into an elongate triangular lobe ventrally, strongly sclerotized, finely setosed; cucullus well developed, broad, triangular in outline, neck very narrow, strongly dilated apically, top broad, round, ventrally directed, distally bearing fine hair; aedeagus moderate, slightly curved, gradually tapering, tip rounded, vesica bearing a single moderate cornuti, caulis rod like, weak. 


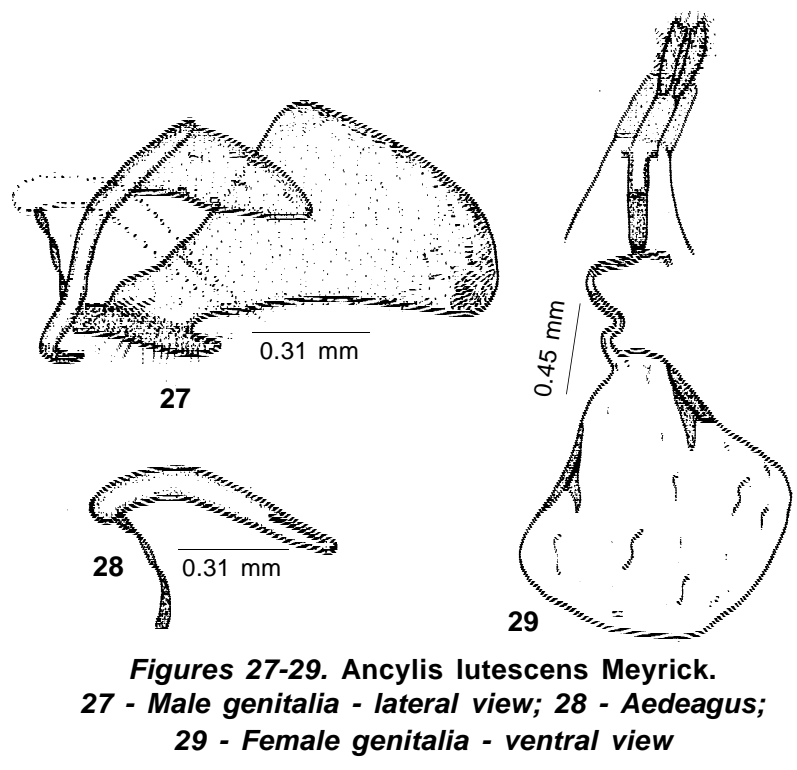

Female genitalia (Fig. 29): Papillae anales flat, long and narrow, anterior apophyses longer than posterior; sterigma simple; ostium bursae wide; ductus bursae moderate, proximal half sclerotized, membranous part narrower than sclerotized, corpus bursae large, globular, bearing two strong thorn-like signae, base expanded along walls of corpus bursae, disk like.

Alar expanse: Male and female 14-16mm.

Larval host plant: Zizyphus jujuba (Fletcher, 1921).

Remarks: The species, under reference, has been identified as Ancylis lutescens Meyrick from Meyrick (1912) and Clarke (1958) besides personal examination and comparison with the lectotype (Bengal, Pusa, male, 19.10.07, slide JFGC-6973) in the NHM, London. As an exceptional case, Meyrick (1912) has mentioned that this is the only species of the genus (i.e., Ancylis Hübner) having a costal fold in the male. It may also be mentioned that Horak and Brown (1991) while giving the diagnosis of the tribe Eucosmini have mentioned that the male often have sex scales either on the costa of the forewing or in the fold of anal margin in the hindwing in the genus Ancylis Hübner. Also, the signum is quite peculiar and is represented by the sclerotized walls of the corpus bursae and this distinctive sclerotization does not justify shifting the genus to another tribe i.e., Enarmoniini (Diakonoff, 1953; Kuznetsov \& Stekolnikov, 1984). Accordingly, following Horak and Brown (1991) besides for want of more species of this genus, the present arrangement i.e., reporting it under the tribe Eucosmini is followed. The recording of this species from Patiala (Punjab) is an additional record from northwestern India.

\section{Eucosma Hübner}

Eucosma Hübner, [1823], Zuträge Samml. Exot. Schmett., 2: 28. Catoptria Guenée, 1845, Annls Soc. Ent. Fr., (2) 3: 187. Typespecies: Phalaena pupillana Clerck, 1759, Icon Insect. Rariorum,
1: pl. 11, fig. 9 .

Ioplocama Clemens, 1860, Proc. Acad. Nat. Sci. Philad., 1860: 360. Type-species: Ioplocama formosana Clemens, 1860, ibidem, 1860: 360, by monotypy.

Affa Walker, 1863, List Specimens lepid. Insects Colln Br. Mus., 27: 202. Type-species: Affa bipunctella Walker, 1863, ibidem, 27: 202 , by monotypy.

Joplocama [sic] Walker, 1864, List Specimens lepid. Insects Colln Br. Mus., 30: 994.

Exentera Grote, 1877, Can. Ent., 9: 227. Type-species: Exentera apriliana Grote, 1877, ibidem, 9: 227, by monotypy.

Exenterella Grote, 1883, Can. Ent., 15: 23. Type-species: Exentera apriliana Grote, 1877, Can. Ent., 9: 227. Replacement name for Exentera Grote.

Eucosmoides Obraztsov, 1946, Z. Wien, Ent. Ges., 30: 38. Typespecies: Grapholita decolorana Freyer, [1840] 1842, Neure Beitr. Schmett. 4: 48, pl. 318, fig. 5 by original designation and monotypy. Type-species: Eucosma circulana Hübner, [1823], ibidem, 2: 28, figs. 363,364 , by subsequent designation by Fernald.

\section{Discussion}

While dealing with type specimens of Microlepidoptera in the British Museum (Natural History) described by Edward Meyrick, Clarke (1958) has given the photographs of the genitalia of 26 Indian species out of a total of 88 species referable to the genus Eucosma Hübner. After critical consultation of this work, four species i.e., E. chloromima Meyrick, E. melanoneura Meyrick, E. prominens Meyrick and E. stereoma Meyrick have been identified during the course of present studies. Their identification has also been confirmed after examination of the lectotypes (female, Kwanshien, China, F.7.30, slide no. JFGC7095; male, Khasi Hills, Assam, 10.1906, slide no. JFGC-6992; female, Punjab, Muree, 6.18, slide no. JFGC-7038; male, Bengal, Pusa, 4.8.11, slide no. JFGC-6978 respectively) in the NHM, London. Apart from this, one species is described as $E$. pseudostrigulata sp. nov. According to Diakonoff (1968, 1971, 1975, 1982) the genus Eucosma Hübner contains the heterogeneous material and so far the exact placement of different species either warrant new genera or require shifting of such species, hitherto reported under Eucosma to new genera to form new combinations. The examination of the male genitalia of presently identified species reveals that the species i.e., $E$. chloromima, E. prominens and E. strigulatus sp. nov. are broadly congeneric and form a single natural group, whereas, the other two i.e., E. melanoneura and E. stereoma drastically differ not only from the previous group of three species but also from each other. However, this could not be ascertained on the basis of the female genitalia, which is available only for two species viz., E. stereoma and E. chloromima. Though the wing venation has been found to be quite consistent in all the five species yet an overall assessment reveals that either these species require new genera or need to be shifted to some other known Eucosmin genera. However, this step is deferred for the time being for want of information of the type-species i.e., Eucosma circulana Hübner of the genus Eucosma Hübner. Subject to more collection (particularly females) and further studies, the arrangement given by Clarke (1958) has been followed in the present work. 


\section{Eucosma stereoma Meyirk}

Eucosma stereoma Meyrick, 1912, Exot. Microlepid., 1: 33. Clarke, 1958, Cat. type-spec. Microlepid. BMNH described by Edward Meyrick, 3: 391.

Material examined: 11 females, 7 males, 22-25.iv.1999, 1 male, 17.iv.2000, FRI, Dehradun, Uttaranchal, 700m.

Distribution: India (Bengal, Pusa).

\section{Diagnostic features}

Male genitalia (Fig. 30): Uncus, socii, gnathos absent; tegumen weak, high, somewhat rounded, a group of fine hair below apex laterally; vinculum weak; valva simple, basal excavation moderate, saccular margin broad, beset with fine sparse hair; cucullus broad, clavate, neck moderate, top rounded, distal margin with a row of strong spines; aedeagus long, slender, globular basally, slightly curved, caulis long, thin, band-like.

Female genitalia (Fig. 31): Papillae anales long, slender; anterior apophyses slightly longer than posterior apopheses; sterigma simple; ostium bursae moderate; seventh sternite moderately sclerotized; ductus bursae small; corpus bursae globular in shape, with a pair of thorn-like signae present.

\section{Alar expanse: Male and female 10-11mm.}

Larval host plant: Pithecolobium dulce (Fletcher, 1921).

Remarks: This species can be easily identified on the basis of presence of a patch of flocculent white scales at basal one-third of costa of the forewing. The aedeagus is also somewhat unique being rounded and globular anteriorly. The caulis is also very long. Though Meyrick (1922) has examined only two specimens while reporting it new from Pusa (India), the present survey shows that the species is moderately common in the Siwaliks.
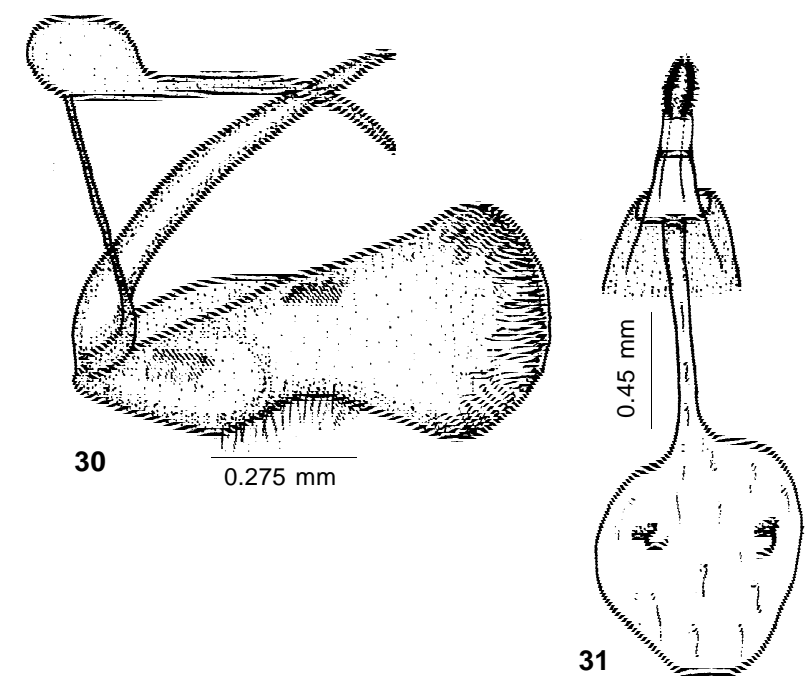

Figures 30-31. Eucosma stereoma Meyrick. 30 - Male genitalia - lateral view; 31 - Female genitalia ventral view
Also, it may be mentioned that the number of males collected is generally more but in the present case the females outnumber the males. The present data is also a new distributional record for this species from northwestern India.

\section{Eucosma melanoneura Meyrick}

Eucosma melanoneura Meyrick, 1912, J. Bombay Nat. Hist. Soc., 21: 866. Clarke, 1958, Cat. Type-spec. Microlepid. BMNH described by Edward Meyrick, 3: 372. pl. 185 figs. 2-2a.

Material examined: 1 male, 12.ix.1999, UHF, Nauni, Solan, Himachal Pradesh, 1360m.

Distribution: India (Khasi Hills) (Meyrick, 1912).

\section{Diagnostic features}

Male genitalia (Figs. 32-33): Uncus small, broad, bilobed, lobes rounded; socii small, somewhat clavate, top rounded, sparsely with fine hair, gnathos vestigial, represented by two membranous arms attached below tuba analis; tuba analis moderately sclerotized, tegumen moderate, high, V-shaped; valva moderate, narrow medially, strongly dilated distally, clavate, costa produced into a prominence terminally, medially concave, sacculus moderate, medially broad, with a bunch of long hair, a group of fine bristles terminally; cucullus neck long and narrow, with a row of 7-8 slender and long spines ventrally, distally dilated strongly and abruptly, apex rounded, inner surface with dense hair, ventral margin obliquely with a row of small but stout spines; aedeagus strongly built, slightly curved, top rounded, with a sheaf of long cornuti; caulis small, thin.

Female genitalia: Not examined.

Alar expanse: Male 12mm.

Larval host plant: Rhus semialata (Fletcher, 1921).

Remarks: The species, under reference, has earlier been described on the basis of one male and one female specimen from Khasi Hills in North East India by Meyrick (1912). During the course of present surveys, a single specimen collected from Nauni (HP) has been identified as Eucosma melanoneura in view of certain specific diagnostic characters such as the wings having veins black and undersurface of the forewing carries a
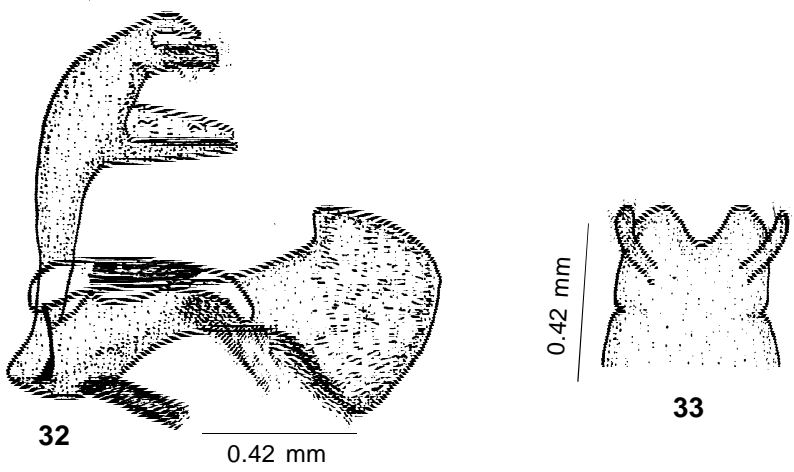

33

Figures 32-33. Eucosma melanoneura Meyrick. 32 - Male genitalia - lateral view; 33 - Tegumen - ventral view 
black patch on its costal margin. Out of two specimens (Meyrick, 1912), Clarke (1958) has fixed the male as a lectotype (slide no. JFGC-6992) of this species. The detailed examination of the male genitalia shows that the bilobed uncus with a pair of socii are quite unique in this species. This present collection is an additional distributional data for this species.

\section{Eucosma pseudostrigulata sp. nov.}

\section{Material examined}

Holotype: Male, 23.iv.1999, FRI, Dehradun, Uttaranchal, 700m.

Etymology: The name is proposed due to the presence of false costal strigulae on its forewing.

\section{Diagnostic features}

Male: Vertex and frons whitish-ochreous; antenna filiform, whitish grey, with black bands; labial palpus long, porrect, 2.6 times diameter of eye, second segment beset with very long whitish ochreous scales, with some fuscous suffusion, reaching beyond tip of third segment, third segment dark fuscous, hardly visible, hidden inside scales of second segment (Fig. 34); forewing with costa almost straight, hardly arched, apex pointed, termen moderately concave, tornus obtuse, anal margin slightly arched, covered with pale ochreous scales throughout with longitudinal suffusion and irregular patches of grey and light brown scales, an occeloid whitish-ochreous patch, two longitudinal patches of black scales along with three black

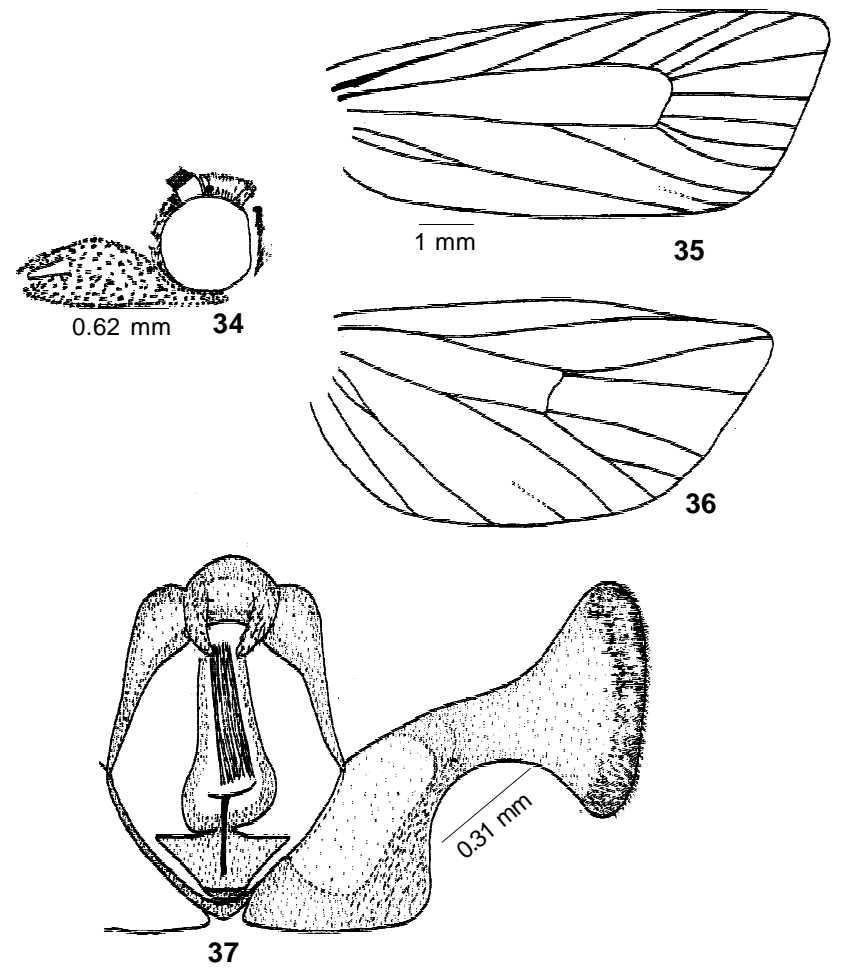

Figures 34-37. Eucosma pseudostrigulata sp. nov. 34 - Labial palpus; 35 - Forewing venation;

36 - Hindwing venation; 37 - Male genitalia - ventral view specks, costal strigulae not defined, dark brown and pale ochreous oblique lines and patches along costa representing false strigulae, fringes with cilia dark grey, latter with black base and whitish apices, tornal cilia long and creamish, undersurface greyish fuscous except costa, latter with a whitish patch towards distal half; hindwing quadrate, uniformly grey throughout, fringes long, whitish-grey with dark sub-basal shade, undersurface greyish fuscous throughout, legs creamish.

Wing venation (Figs. 35-36): Forewing with Sc ending before middle of costal margin, $\mathrm{R}_{1}$ arising before middle of cell, $\mathrm{R}_{2}$ arising towards $R_{3}$ than $R_{1}, R_{4}$ and $R_{5}$ free, $R_{4}$ arising from upper angle of cell, ending at costa, $R_{5}$ ending at termen, $M_{1}$ and $M_{2}$ almost straight and parallel, $\mathrm{M}_{3}$ and $\mathrm{CuA}_{1}$ free, $\mathrm{CuA}_{1}$ arising from lower angle of cell, $\mathrm{CuA}_{2}$ from well beyond middle of cell, $\mathrm{CuP}$ visible only in the distal end, $1 \mathrm{~A}+2 \mathrm{~A}$ forked at base, fork extending beyond one-fourth, chorda and M-stem absent; hindwing with $\mathrm{Sc}+\mathrm{R}_{1}$ ending in the posterior one-fourth of costal margin, Rs and $M_{1}$ closely approximated at base, $M_{2}$ bent towards lower angle at base, $\mathrm{M}_{3}$ and $\mathrm{Cu}_{1}$ long stalked, stalk extending beyond middle, $\mathrm{CuA}_{2}$ arising almost in the middle of cell, $\mathrm{CuP}$ visible only distally, $1 \mathrm{~A}+2 \mathrm{~A}$ forked at base, fork small, 3A present, slightly diverging distally.

Male genitalia (Fig. 37): Uncus absent; socii moderate, drooping, semi-oval pads, sparsely hairy; tegumen moderate in size, high, top somewhat rectangular, shoulders produced; vinculum weak, U-shaped; juxta triangular, plate-like; valva deeply constricted almost in middle, costa straight, sacculus moderate, medially produced into a somewhat triangular protuberance, with numerous fine setae, basal excavation moderate, cucullus neck narrow, apex strongly clavate, more or less rounded, hammer shaped, produced into two almost equal sized lobes, inner surface with long dense hair, distal margin with a row of small but stout spines; aedeagus short, broad, anteriorely bulbous, vesica with a sheaf of cornuti; caulis small, weak.

Female genitalia: Not examined.

\section{Alar expanse: Male 20mm.}

\section{Larval host plant: Unknown}

Remarks: One specimen representing the tribe Eucosmini could neither be identified from the national reference collections housed at FRI, Dehradun nor from the NHM, London and is presently named as Eucosma pseudostrigulata sp. nov. The species is somewhat allied to Epiblema ancyrota Meyrick (Meyrick, 1907). However, Clarke (1958) has proposed a new combination of the latter species under the genus Epinotia Hübner but Diakonoff (1966) has preferred to keep ancyrota under the genus Eucosma Hübner. The present study shows that both the species are somewhat allied to each other as for as the structure of the uncus, socii and the valvae in the male genitalia are concerned. However, these can easily be separated on the basis of the costal fold in the forewing, which is strongly developed in ancyrota and completely wanting in Eucosma pseudostrigulata sp. nov. 


\section{Eucosma chloromima Meyrick}

Eucosma chloromima Meyrick, 1931 in Caradja, Bull. Sect. Sci. Acad. roum., 14: 65. Clarke, 1958, Cat. Type-spec. Microlepid. BMNH described by Edward Meyrick, 3: 355, pl. 176, figs. I-Ic.

Material examined: 1 female, 1 male, 12.ix.1999, UHF, Nauni, Solan, Himachal Pradesh, 1,360m, 12.ix.1999.

Distribution: India (Dalhousie, Kashmir), China (Clarke, 1958).

\section{Diagnostic features}

Male genitalia (Fig. 38): Uncus absent; socii large, curved, semioval pads, densely hairy; tegumen moderately broad, high, top rounded, shoulders produced; vinculum weak, U-shaped; juxta triangular, plate-like; valva long and broad, simple, somewhat semi-oval, slightly broadening towards apex, costa convex, basal excavation large, sacculus narrow, cucullus long, broad, somewhat rectangular in outline, slightly expanding distally, apex more or less rounded, inner surface densely hairy; aedeagus moderately long and broad, slightly curved, gradually tapering, lower lip pointed, vesica with a sheaf of long cornuti.

Female genitalia (Fig. 39): Papillae anales long, slender; posterior apophyses longer than anterior apophyses, each with terminal end clavate; seventh sternite slightly sclerotized; ostium bursae wide; ductus bursae moderate, proximal half sclerotized from both ends, gradually widening distally; corpus bursae long, globular, with two straight horn-like signae; ductus seminalis enter in the middle of ductus bursae near sclerotized part.

\section{Alar expanse: $17-18 \mathrm{~mm}$.}

\section{Larval host plant: Unknown}

Remarks: Upon dissection, the female genitalia of the species, under reference, has been compared with its lectotype (slide no. JFGC-7095) lying in the NHM, London. Besides giving an illustrated account of the female genitalia, the male genitalia is

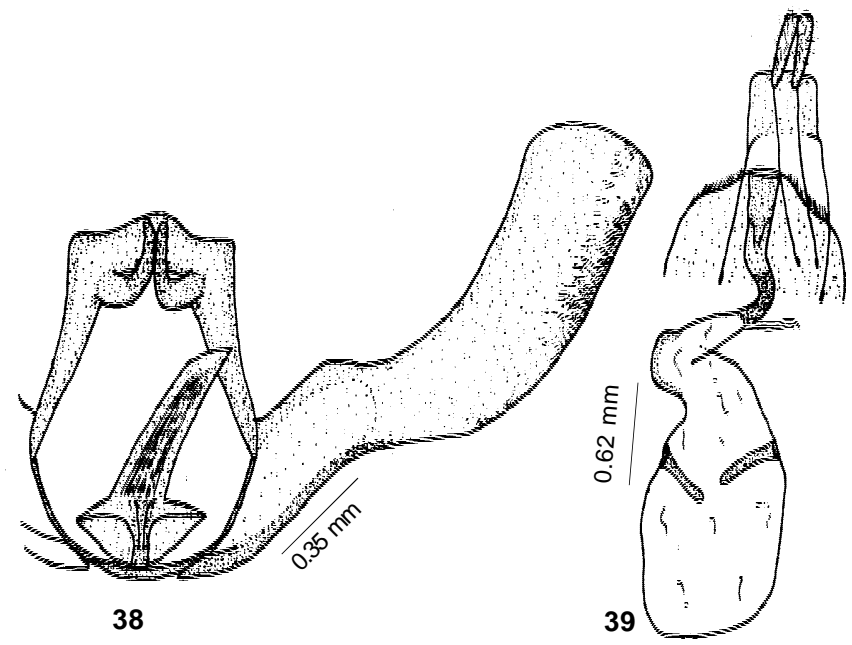

Figures 38-39. Eucosma chloromima Meyrick. 38 - Male genitalia- ventral view; 39 - Tegumen- ventral view described for the first time. The reporting of the species from Nauni (HP) is the second record from northwestern India as it has earlier been reported from Dalhousie and Kashmir (Meyrick, 1931; Clarke, 1958).

\section{Eucosma prominens Meyrick}

Eucosma prominens Meyrick, 1922, Exot. Microlepid. 2: 517. Clarke, 1958, Cat. type-spec. Microlepid. BMNH described by Edward Meyrick, 3: 383, pl. 190 figs 4-4c.

Material examined: 1 male, 26.iv.1999, FRI, Dehradun, Uttaranchal, 700m; 1 male, 30.xi.1999, Vikasnagar, Dehradun, Uttaranchal.

Distribution: Pakistan (Punjab, Muree) (Clarke, 1958).

\section{Diagnostic features}

Male genitalia (Fig. 40): Uncus absent, socii broad, slightly curved, semi-oval pads, each densely hairy; tegumen moderate, high, somewhat rectangular, triangularly produced, pointed, vinculum U-shaped; juxta rectangular, plate-like: valva broad, simple, slightly narrow basally, costa strongly convex, basal excavation moderate, sacculus broad terminally, cucullus delimited by a small broad neck, cucullus broad, slightly curved dorsally, dorsal margin concave, ventral margin convex, top more or less rounded, inner surface with numerous long dense hair, a group of very fine setae in the middle of valva after basal excavation; aedeagus long, slender, anteriorly bulbous, almost straight, vesica with a sheaf of long cornuti; caulis small, bandlike.

Female genitalia: Not examined.

Alar expanse: Male $18 \mathrm{~mm}$.

Larval host plant: Unknown

Remarks: The species has been identified as Eucosma prominens Meyrick from the description given by Meyrick (1922)

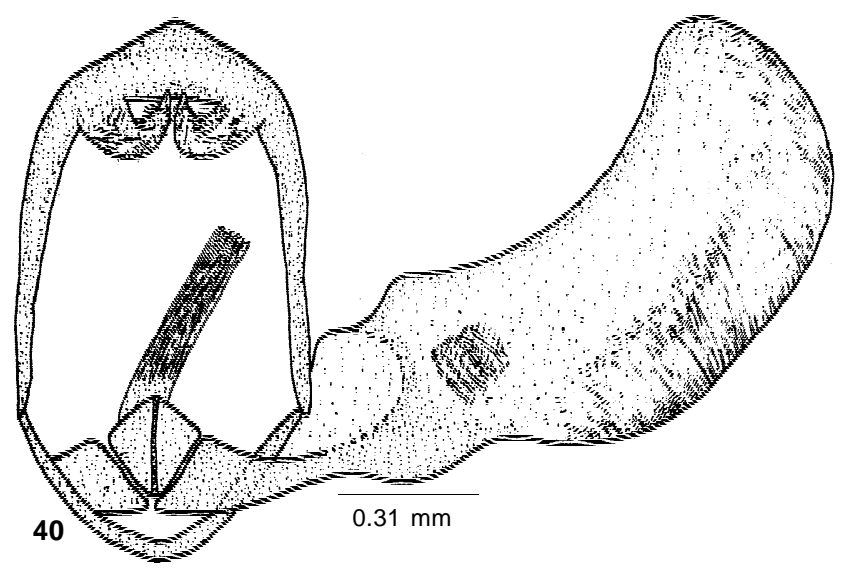

Figure 40. Eucosma prominens Meyrick. 40 - Male genitalia- ventral view 
who named it on the basis of two female specimens from Pakistan (Muree). The species is being recorded for the first time from India. Though no female could be collected yet the male genitalia is described for the first time. Clarke (1958) while designating the lectotype has examined the female genitalia of this species as well as that of chloromima and has mentioned that both the species are probably allied to each other. This observation is also supported after the examination of the male genitalia of both these species during the course of present studies.

\section{Conclusion}

On the basis of studies pertaining to 16 species belonging to eleven genera viz., Rhopobota Lederer, Acroclita Lederer, Strepsicrates Meyrick, Gibberifera Obraztsov, Loboschiza Diakonoff, Crocidosema Zeller, Epinotia Hübner, Helictophanes Meyrick, Acanthoclita Diakonoff, Ancylis Hübner and Eucosma Hübner, it has been observed that the cucullus part of the valva is well developed and is delimited by a neck in the male genitalia of all the species. However, the female genitalia of only seven species viz., Strepsicrates rhothia (Meyrick), Gibberifera glaciata (Meyrick), Loboschiza koenigiana (Fabricius), Crocidosema plebejana (Zeller), Ancylis lutescens Meyrick, Eucosma stereoma Meyrick and E. chloromima Meyrick could be studied and it has been noticed that a sclerotized ring near the entry of the ductus seminalis is always present. Apart from this, the veins $\mathrm{CuA}_{1}$ and $\mathrm{M}_{3}$ are always stalked in all the species, presently studied.

Further, it has been evident from the literature that the tribe Eucosmini does not contain homogenous group of taxa in view of it being evolved from more than one ancestor in the tribe Olethreutini (Horak \& Brown, 1991). Perhaps, in view of this, Diakonoff (1973), and Kuznetsov and Stekolnikov (1984) have referred the genus Ancylis Hübner (presently studied) besides two more genera i.e., Enarmonia Hübner and Eucosmomorpha in the tribe Enarmoniini. However, following the interpretation made by Horak and Brown (1991), the genus Ancylis Hübner is derived from Olethreutini and its placement in the tribe Enarmoniini is apparently wrong. Accordingly, this is kept in the tribe Eucosmini in the present studies.

\section{REFERENCES}

Clarke, J.F.G. (1958). Catalogue of the Type specimens of Microlepidoptera in the British Museum (Natural History) described by Edward Meyrick, III: 600pp, 298pls.

Common, I.F.B. (1970). Lepidoptera (Moths and butterflies). In: The Insect of Australia. Melbourne University Press, Melbourne: 866pp.

Diakonoff, A. (1950). The type specimens of certain Oriental Eucosmidae and Carposinidae. Bulletin of the United States National Museum 275-300,
4-8 pls.

Diakonoff, A. (1953). New Guinean Microlepidoptera IV. 56(4): 474-485. Diakonoff, A. (1973). The South Asiatic Olethreutini (Lepidoptera: Tortricidae). Zoology Monogaph Rijksmus Naturelle Histoire 1: I-XXII, 1700. 732 figs., 14 pls.

Diakonoff, A. (1982). On a collection of some families of Microlepidoptera from Sri Lanka (Ceylon). Zoology Verh Leiden 193: 1-124, 18pls.

Fletcher, T.B. (1921). Life histories of Indian Insects (Microlepidoptera). Department Agriculture India (Entomology) 6: 1-217.

Horak, M. and Brown, R.L. (1991). Morphology, Phylogeny and Systematics 1.1. Morphology. In: Tortricid Pests, Their Biology, natural enemies and Control. Elsevier B.V. Amsterdam, 22pp.

Kawabe, A. and Nasu, Y. (1994). A revision of the genus Gibberifera Obraztsov (Lepidoptera: Tortricidae) with description of four new species. Tyô to $G a$ 45(2): 79-96.

Kuznetsov, V.I. and Stelkonikov, A.A. (1984). Classification and phylogenetic association between families and sueperfamilies of the the Lepidopteran infraorder Papilionomorpha (Lepidoptera: Copromorphoidea, Elachistoidea, Coleophoroidea, Gelechioidea), taking into account functional morphology of male genitalia. Trud. Zool. Inst. Akad. Nauk USSR (St. Petersburg), 122: 3-68.

Meyrick, E. (1912). Descriptions of Indian Microlepidoptera. Journal of the Bombay Natural History Society 22: 160-182.

Meyrick, E. (1912-1916). Exotic Microlepidoptera I: 640pp.

Meyrick, E. (1916-1923). Exotic Microlepidoptera II: 640pp.

Meyrick, E. (1930-1936). Exotic Microlepidoptera IV: 642pp.

Obraztsov, N.S. (1967). Some Apocryphal species of the Tortricidae (Lepidoptera: Tortricidae). Journal of the New York Entomological Society LXXV(1): 34.

Razowski, J. (1977). Monograph of the genus Archips Hübner (Lepidoptera: Tortricidae) Acta Zoologica Cracov XXII(5): 55-233.

Robinson, G.S. (1976). The preparation of slides of Lepidoptera genitalia with special reference to Microlepidoptera. Entomology Gazette 27(2): 127-132.

Robinson, G.S., Tuck, K.T. and Shaffer, M. (1994). A Field Guide to the smaller moths of South-East Asia. Malaysian Nature Society, 482pp.

Zimmerman, E.C. (1978). Microlepidoptera. Insects of Hawaii, Vol. 9. University Press of Hawai, Honolulu, xviii+1903pp.

\section{ACKNOWLedgements}

Prof. H.S. Rose is grateful to the Ministry of Environment and Forests (Govt. of India), New Delhi for funding the project on Microlepidotpera and to the Vice-Chancellor, Punjabi University, Patiala for providing all necessary facilities to set up the Coordinating Centre under an All India Coordinated Project on Taxonomy (AICOPTAX) programme of the Central Government. HSR is also thankful to Mr. Onkarpreet Singh Jutla for setting the text of the electronic version. Authors are also thankful to some of the overseas workers like Jozef Razowski (Poland), B.K. Byun, K.T. Park (Korea), Kevin Tuck (UK), Marianne Horak (Australia), Richard Brown and John Brown (USA) for sending valuable reprints of their publications and timely suggestions on certain specific issues. Special thanks are due to Dr. Nieukerken (The Netherlands) for sending a set of publications by late Dr. Alexei Diakonoff. Alongwith granting the necessary permission, the cooperation rendered by Mr. David Carter, Incharge, Microlepidoptera section and Mr. Kevin Tuck during examination of type material at the Natural History Museum, London is acknowledged gratefully.

\section{Key to the species of the genus Epinotia Hübner}

1. Forewing ground colour a mixture of whitish ochreous to dark fuscous, costal area dominantly fuscous, anal area whitish ochreous, a small oval black spot at apex; male genitalia with uncus simple, rounded apically, socii well developed, large, fleshy pads, valva with sacculus broad, bearing a large triangular prominence ...................................................................................................................................... corynetes Diakonoff $1 \mathrm{~A}$. Forewing ground colour greyish with a uniform suffusion of dark fuscous, termen with a dark fuscous line throughout, male genitalia with uncus small, bipartite apically, socii relatively less developed, small, drooping pads, valva with saccular margin convex .... canthonias Meyrick 


\section{Key to the genera of the tribe Eucosmini}

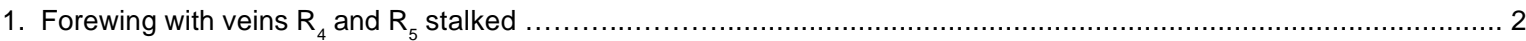

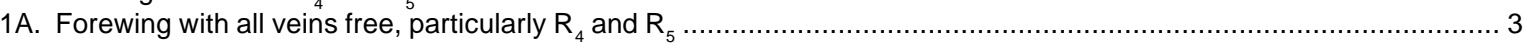

2. Male genitalia with tegumen with two strong arms arising below middle, joined apically Rhopobota Lederer

2A. Male genitalia with tegumen without any arms Acroclita Lederer

3. Male genitalia with uncus present ...... 4

$3 \mathrm{~A}$. Male genitalia with uncus wanting 8

4. Male genitalia with uncus bilobate or represented by two laterally directed arms 5

4A. Male genitalia with uncus not as above, simple, single lobe or absent 6

5. Male genitalia with valva uniformly broad throughout, cucullus not separated by a constriction, cucullus with a set present ventro-medially, uncus represented by two lateral arms; female genitalia with corpus bursae with signum wanting Strepsicrates Meyrick

5A. Male genitalia with valva not uniformly broad throughout, cucullus separated by a constriction in the middle, cucullus with a seta present at base ventrally, uncus not as above, stick-shaped, forked at base only; female genitalia with two thorn-like signae present

Gibberifera Obraztsov

6. Adults usually brightly coloured, orange or red; male genitalia with uncus absent, valva with cucullus lobate..... Loboschiza Diakonoff

6A. Adults never brightly coloured; male genitalia with uncus present, valva with cucullus not bilobate

7

7. Male genitalia with cucullus much broader than sacculus, delimited by a strongly constricted neck, twisted ventrally

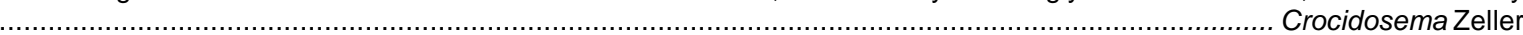
7A. Male genitalia with cucullus strongly or somewhat narrower than sacculus, delimitation not clear, cucullus simple, rounded Epinotia Hübner

8. Male genitalia with cucullus somewhat or strongly dilated than sacculus 9

8A. Male genitalia with cucullus much narrower than sacculus

Helictophanes Meyrick

9. Valva with sacculus quite reduced, cucullus gradually but strongly dilated, delimitation not clear, socii absent Acanthoclta Diakonoff 9A. Male genitalia with sacculus well developed, cucullus separated by a slight or deeply constricted neck, socii present, well developed 10

10. Forewing always with anal fold present in male; male genitalia with socii large, single, fleshy pad, valva with cucullus separated by an abruptly and deeply constricted neck, more or less triangular; female genitalia with wall of corpus bursae sclerotized to form two flat and triangular signae.....

Ancylis Hübner

10A. Forewing always without anal fold in male; male genitalia with socii represented by small to medium pads, latter drooping, valva with cucullus separated by a slight constriction or a broad neck, broad, somewhat rounded in shape; female genitalia with corpus bursae not as above, signae thorn-shaped

Eucosma Hübner

\section{Key to the species of the genus Eucosma Hübner}

1. Alar expanse less than $13 \mathrm{~mm}$ 2

1A. Alar expanse more than $16 \mathrm{~mm}$

2. Male genitalia with tegumen well developed, socii present, valva with cucullus strongly expanded, about three times broader than base, aedeagus uniformly broad throughout .............................................. stereoma Meyrick 2A. Male genitalia with tegumen reduced, socii absent, valva with cucullus slightly expanded than base, aedeagus globular anteriorly melanoneura Meyrick

3. Forewing with costa lacking true costal strigulae, furnished with prominent dark brown and pale ochreous lines and bands; male genitalia with cucullus separated by a deeply constricted neck, cucullus hammer-shaped pseudostrigulatasp. nov. 3A. Forewing with costa having whitish costal strigulae; male genitalia with cucullus not as above, simple ............... 4

4. Male genitalia with tegumen pointed apically, shoulder absent, valva broad, cucullus more than twice broad than base

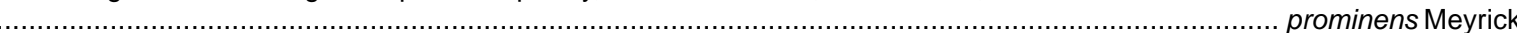
4A. Male genitalia with tegumen rounded apically, shoulder produced, valva long and slender, cucullus almost as broad as base chloromima Meyrick 